\title{
Democracy and the Body Politic from Aristotle to Hobbes
}

\author{
Sophie Smith, Christ Church, Oxford
}

\begin{abstract}
The conventional view of Hobbes's commonwealth is that it was inspired by contemporary theories of tyranny. This article explores the idea that a paradigm for Hobbes's state could in fact be found in early modern readings of Aristotle on democracy, as found in Book Three of the Politics. It argues that by the late sixteenth century, these meditations on the democratic body politic had developed claims about unity, mythology, and personation that would become central to Hobbes's own theory of the commonwealth. Tracing the history of commentary on the relevant passages in Aristotle reveals new perspectives not only on the political theories of both Aristotle and Hobbes but also introduces modern readers to the richness of early modern commentaries on classical political texts. The article ends with some thoughts on why attention to traditions of commentary might be valuable for political theorists today.
\end{abstract}

\section{Keywords}

Aristotle, Hobbes, democracy, commonwealth, union, commentary

What did it mean to think about democracy when democracy was unthinkable? Historians of political theory often take one of two approaches to democratic thought in the centuries between democracy's collapse in ancient Athens and its broad revival as the name of a legitimate political option in nineteenth-century Europe. ${ }^{1}$ The first focuses on authors who looked backwards, reflecting on democracy as a purely historical phenomenon, a form of government to be understood and evaluated through extant treatises, artifacts, and literary texts. The second looks to authors writing about politics before modern democracies emerged, but in whose works are found hints or springs of modern democratic theory.

Thomas Hobbes (1588-1679) has often been the subject of this second approach. Was he, as some suggest, the "true ancestor of constitutional liberal democracy"? Or perhaps he is best understood as a nascent "radical democrat"? ${ }^{2}$ Richard Tuck recently offered a new case for the democratic Hobbes which looks both forwards and backwards: on the one hand Hobbes (however unwittingly) provided a "new theory of democracy" as it has been understood since the French revolution, whereby democratic sovereigns could license undemocratic administrations. ${ }^{3}$ On the other hand, Tuck's Hobbes was also a serious reader of contemporary attempts to grapple with ancient accounts of democracy, and whose own political philosophy was especially influenced by an account of "extreme democracy" that came to him via early modern commentaries on Book Four of Aristotle's Politics. The model of civic unity that Hobbes found there became, Tuck argues, a paradigm for Hobbes's own 
theory of the body politic. Hobbes's critique of "mixed" commonwealths rests, then, not (as has long been accepted) on an understanding of monarchy, but instead on an understanding of democracy.

Historians of political thought have found much to object to in Tuck's case for the democratic Hobbes.4 One claim, however, remains too little examined and too quickly dismissed: that Hobbes's "political theory in general was more influenced by his reflections on the character of democratic government than we often realise." 5 One of this essay's aims is to show that we continue to miss this dimension of Hobbes's thought because there remains so much to be recovered about how early modern authors thought about democracy: the critical responses to Tuck, whilst in some regards fair, have nonetheless closed down a space that needs to be opened up. There is much left to say about what it meant to reflect on the character of democracy in early modernity.

This article has five parts: in the first I isolate the central features of Hobbes's theory of the body politic across each of his works of political theory. I then review Tuck's argument that Hobbes took inspiration for this theory of commonwealth from Aristotelian extreme democracy. Here I argue that, whilst Tuck has certainly pointed scholars in a new and suggestive direction, his is an over-abbreviated, and so misleading, account of Aristotelian democracy. For this reason I return in the third section to a key part of Aristotle's own account of the democratic body politic as outlined in Book Three Chapter Eleven of the Politics. This is a passage that has long animated both contemporary political theorists and historians of political thought (not least the rival interpretations of Jeremy Waldron and Daniela Cammack offered in these pages). ${ }^{6}$ It is also, I will argue, essential to understanding Aristotle's claims about extreme democracy in Book Four of the Politics (upon which Tuck's account is based), to appreciating the nature of Aristotle's democratic body politic more broadly, and to unlocking a new story about early modern theories of the democratic body politic. The fourth section looks at a range of such interpretations from the thirteenth to the late sixteenth centuries. With these reflections in hand, I return in the final section to Hobbes. This key period in the history of Aristotelian political theory reveals, I argue, new dimensions of Hobbes's own thought about the commonwealth, and, more broadly, about early modern perspectives on the nature and ends of political theory itself.

Throughout I focus, as does Tuck, on Hobbes's model of commonwealths by institution, not by acquisition, a distinction he maintains in each of his three major works of political theory, The Elements of Law (1640), De cive (1642) and Leviathan (1651). In the conclusion to the paper I offer some reflections on why, despite recent claims to the contrary, we should continue to take Hobbes's account of such commonwealths seriously. ${ }^{7}$ I further suggest that the history I trace here can offer a new perspective on the debates concerning Hobbes's decision to make democracy foundational for instituted commonwealths in both the Elements of Law and in De cive and why too, even when removed in name from Leviathan, its traces are still so clearly evident there.

In this discussion of the ideas of the body politic from Aristotle to Hobbes the route between those two authors is charted via a genre now little studied but once central to the practice of philosophy: the commentary. I will offer some comments at the end of this paper on what kinds of intellectual space investigating historical traditions of commentary might open up for political theorists today. 


\section{Concord, Union and the Hobbesian Body Politic}

At the centre of Hobbes's political theory is an analysis of what he calls "the nature of the body politic," which he refers to variously as the commonwealth, the city, the state, and the civitas. ${ }^{8}$ At the heart of Hobbes's argument about the commonwealth properly understood is the distinction between concord and union. Many of the authors whom Hobbes held most responsible for Europe's recent strife (from the late sixteenth-century French "monarchomachs" to the more proximate supporters of the English Parliament) had made arguments in support of mixed commonwealths, or mixed sovereignty, which assumed-erroneously, Hobbes believed-that the members of a commonwealth were bound by concord. Such authors drew on any number of classical sources for support, from Cicero's conception of the civitas as a concordia ordinum to Aristotle's claim in Book Two of the Politics that the polis is a plurality composed of cooperating parts, not a unity of commonality. ${ }^{9}$ Yet what for Aristotle signalled the best human community - the concord of citizens directing their lives to the common good, of distinct parts cooperating for the sake of the whole-signalled for Hobbes a deep misunderstanding of the nature of the commonwealth, of the humans who made it, and the kinds of sacrifice its formation required.

By contrast, in every version of his political theory, Hobbes insists that the body politic is not an association of men in concord (consensio or concordia ${ }^{10}$ ) but a union (unio). As he put it in the Elements of Law, "there is no way imaginable" for men to join their strengths together against a common enemy "but only union." 11 Advocates of the "mixed commonwealth," he says in the Elements of Law, have reached their flawed constitutional conclusions on the basis of a misunderstanding about the very nature of what they are discussing. Accepting that the commonwealth is a union precludes any argument for mixed sovereignty:

"The error concerning mixed government hath proceeded from want of understanding of what is meant by this word body politic, and how it signifieth not the concord, but the union of many men. And though the charters of subordinate corporations be declared to be one person in law, yet the same hath not been taken notice of in the body of a commonwealth or city, nor have any of those innumerable writers of politics observed such union." 12

Hobbes repeatedly insists on the unhappy consequences of this ubiquitous misunderstanding. Righting it is how he imagines one of his central contributions. For readers to come to a correct understanding of the body politic, he argues, they need to understand what it means to speak of union. For Hobbes, this meant grasping three key claims.

The first is that it is a necessary condition of any commonwealth's existence as a union that men covenant each with each to give up their liberty to decide certain matters for themselves. When it comes to decisions about the commonwealth's safety and security, men have to accept that they take on the sovereign's will in place of their own. The fact of this single will, as opposed to a multitude of wills concurring, was the essence of union. And whilst Hobbes changed the precise terms in which he expressed this thought across his various works of political theory, in each iteration he maintained the same distinction between concord as that which left men with their separate wills (even if an end was agreed upon), and union, which involved the replacement of one's individual will with the will of whatever person or group was the sovereign. In this sense, a commonwealth is well understood as a 
construction of wills, ${ }^{13}$ an artifice made by many acts of human will, that provides, artificially, a single will for all men. ${ }^{14}$ The correct understanding of the passage into the commonwealth, on this account, was to see it as facilitated only by the union of each individual man's will to the will of the individual or group. In one sense, then, this union quite simply was the commonwealth.

The second point Hobbes wanted readers to grasp about union was that the commonwealth - the union of wills — could be understood as a civil person [persona civilis].

This union so made, is that which men call now-a-days a BODY POLITIC or civil society; and the Greeks call it $\pi$ ó $\lambda 1 s$ [polis], that is to say, a city; which may be defined to be a multitude of men, united as one person by a common power, for their common peace defence and benefit. ${ }^{15}$

These ideas of union, the will and civil personality are brought together ever more tightly in Chapter 5 of De cive:

A Union so made is called a commonwealth [civitas] or civil society [societas civilis] and also a civil person [persona civilis]; for since there is one will of all of them, it is to be taken as one person; and is to be distinguished and differentiated by a unique name from all particular men, having its own rights and its own property [res sibi proprias]. Consequently, no single citizen, nor all together (except him whose will stands for the will of all) are to be regarded as the commonwealth. A COMMONWEALTH, then, (to define it) is one person, whose will, by the agreement of several men, is to be taken as the will of them all; so that he may make use of their strength and resources for the common peace and defence. ${ }^{16}$

We are left, then, with this equation: the state is a union, understood as a civil person, which exists only as long as there is a sovereign (so much so that at times the idea of the state and the idea of the sovereign can seem to run into one another). ${ }^{17}$ Union is called both the commonwealth and a civil person because it is the fact of a single will, which all have agreed to obey, that makes the commonwealth. Hence, as Hobbes puts it in Chapter Twenty of the Elements, the task of political theory is to explain "how a multitude of persons natural are united by covenants into one person civil or body politic." 18

The third, related point that Hobbes wanted his readers to understand about the nature of union, and thus about the body politic, was that the multitude has no collective existence outside of the sovereign, what he calls in Leviathan the "sovereign representative." One of the most striking ways that he makes this point comes in De cive where he takes on what it is that authors are actually discussing when they deploy the common abstraction "the people." Given that to speak of the "people," we mean not a disparate crowd, but a single agent to whom an act can be attributed, then, Hobbes argues, to speak of the people must simply be to speak of the sovereign. For it is only through the sovereign that the otherwise disparate crowd of subjects can be said to have any collective existence at all. So it was that Hobbes could reach his most knowing paradox: that in a monarchy, the King just is the people. For Hobbes, there is no intermediary collective - no "people"-from whom the sovereign's power comes. There is no 'natural' body that transfers its rights to the sovereign (an argument made by the Jesuit Francisco Suárez (1548-1617), whom Hobbes picks out for criticism by name, as well as by English parliamentarians and so-called republicans across Europe). Again, it matters here that in this strict sense, the commonwealth, the 
sovereign, and the people have a certain identity for Hobbes; no one of them exists before or independent of the other. The multitude make these entities themselves when they covenant to establish a sovereign, but there is no collective existence outside of that act of creation. In Leviathan, Hobbes famously conceptualized this relationship by describing the genesis of the state in terms of the anatomical unity of a human being, in that case as the formation of an artificial man. The man the multitude makes of themselves may be a body, but its soul, and so its animating force, is the sovereign. One cannot exist without the other.

The claim that commonwealths should be understood as a form of union was not as unique as Hobbes liked to suggest, but his particular interpretation of union was certainly unusual. Hobbes's union was total, leaving little room for individual judgment and even, on some readings, conscience. ${ }^{19}$ It is this extreme unity that Richard Tuck argues was taken by Hobbes from a theory of democracy.

\section{Hobbes and Extreme Democracy}

The conventional view has long been that Hobbes's body politic was inspired by contemporary visions of tyranny. Richard Tuck argues that its source was in fact tyrannical democracy, and more specifically, Aristotle's account of extreme democracy as outlined in Book Four of the Politics. ${ }^{20}$ There Aristotle details five types of democracy. In the fifth of these,

the multitude is sovereign not the law... . The people becomes a monarch, one composed of many, for the many are sovereign, not as individuals but as aggregate ... such a people, in its role as a monarch, not being controlled by the law, aims at sole power and becomes like a master . . such a democracy is the counterpart of tyranny among monarchies. ${ }^{21}$

Aristotle is clear that this form of democracy barely merits classification as a form of government, even a perverse form. ${ }^{22}$ This kind of democracy was so unacceptable to Aristotle, says Tuck, precisely because of its unity: in an extreme democracy, men lose their individual identity to a single ruling agent (which they nonetheless comprise), who rules according to its whims and dictates and not according to the law. But it was precisely this unity that, Tuck argues, singled out to early modern authors the extreme democratic account as an alternative theory of the body politic to the conventional classical accounts which emphasized concord, consensus and cooperation. ${ }^{23}$

To demonstrate that the theoretical potential in this contrast was picked up by Aristotle's Renaissance readers Tuck focuses particularly on the contribution of the great Italian humanist Pietro Vettori (1499-1585). In his widely read commentary on the Politics, Vettori added a new gloss to the Book Four description of extreme democracy. It is worth looking at what he says in full:

Aristotle states that in those cities in which no laws have been fixed that would check the fury of the multitude, the people slowly become the master, and rule there alone. Moreover Aristotle shows what difference lies between it [the populus as dominus] and a monarch properly speaking. For that man (i.e., the monarch), is one mortal being who made everything according to his own right: this man by contrast, is joined together from many, as if one man has been 
made out of all those [physical] human beings, of which the people consists, being amalgamated. ${ }^{24}$

For Tuck, the most significant move Vettori makes here is the use of the word "man" to describe the body politic made out of the disparate members of the democracy. ${ }^{25}$ Where the general trope of the "body politic" is ubiquitous in medieval and early modern political literature, references to the respublica as "one man" are rare, precisely because the term emphasised too high a degree of unity. Vettori, then, marks the moment that the potential of Aristotelian democracy is unlocked, and a body politic with the kind of "total unity" Hobbes would advocate first suggested. ${ }^{26}$ Here is a body politic in which the multitude becomes one anatomical man and the individual parts lose their identity to the ruling will of the whole.

It matters too for Tuck that this body politic is democratic in origin. In both the Elements and De cive, and arguably also implicitly in Leviathan, democracy is, somewhat surprisingly, at the foundation of Hobbes's commonwealth by institution: merely by meeting, Hobbes writes in De cive, men make themselves a kind of democracy. ${ }^{27}$ This observation allows Hobbes the striking move of making a single covenant the basis of his state. ${ }^{28}$ And at its foundation is, in the case of instituted commonwealths, democracy.

In summary, Tuck's argument that "extreme democracy" was a paradigm for the well-founded commonwealth' for Hobbes contains three key claims. First that extreme democracies demonstrate a unique form of unity. Second that it was in renaissance readings of extreme democracy that this unity was properly identified and the democratic body politic described as one man. And finally, that this can help us to explain why Hobbes made democracy foundational to commonwealths by institution: democracy was already associated - in the minds of his better read readers at least - with the kind of unity Hobbes wanted to achieve.

Now, Tuck is surely right to alert historians to the philosophical and imaginative potential for Hobbes in extreme democracy, and indeed to suggest that the Hobbesian account of the genesis of the state may have been in part inspired by it. Nevertheless, Tuck's insistence on the singularity of the passage in Book Four of the Politics, and his interpretation of Vettori's gloss of homo there, rests on an incomplete reading of democratic politics both in Aristotle himself and within the later medieval and renaissance commentators. ${ }^{29}$ The conceptual metaphor of the people as one man is not confined, in Aristotle, to discussions of extreme democracy, but to discussions of democracy more generally and, specifically, to the discussion found in Politics Book Three Chapter Eleven. This metaphor of constitution is one constitutive of democratic thinking in this tradition. It is central to Aristotle's theory of democracy and an idea developed in the earliest commentaries on the Politics onwards. The following analysis of this wider history reveals that those features Tuck argues are unique to extreme democracy are in fact part of Aristotle's characterization of democracy at its best as well as its worst.

\section{Democracy and the Body Politic in Aristotle's Politics}

Aristotle's discussion of democracy in Book Four of the Politics has an empirical emphasis absent from Book Three, where it is part of a wider and more abstract meditation on the nature of the city (polis), the idea of a constitution (politeia) and the best location of sovereignty (kurios). It is in Book Three that Aristotle tells us that the city is a multitude of citizens placed in some kind of order $(\text { taxis })^{30}$ and that in all 
constitutions the citizen-body (politeuma) is the sovereign, or highest, power; ${ }^{31}$ thus in a democratic constitution, writes Aristotle, "the people are sovereign." 32 Aristotle's initial and less than sanguine account of democratic constitutions identifies them as the deviation of "polity"; rule not in the common interest but in the interest of those "who have no stock of possessions and are without means." 33 Despite this, in a notorious passage in Chapter Eleven Aristotle identified the conditions under which democratic sovereignty might be not only passable, but preferable.

He begins with the view that "the mass of the people ought to be sovereign, rather than the best but few," a position he notes "is not without difficulty," but which "perhaps has some truth in it." ${ }^{44}$ Discerning this truth relies on considering men as a collective entity:

"For the many (to pletthos) none of whom taken individually is a good" ${ }^{35}$ man (spoudaios), may yet, when taken all together, be better than the few, not individually but collectively ... For even when there are many people, each has some share of virtue (aretē) and practical judgement (phronesis); and when they are brought together, just as they become, as it were, one man who has many pairs of feet and hands and many senses, so also do they become one in regard to character $\left(\right.$ ta èthēe) and thought (dianoia)." ${ }^{\prime} 6$

The key point to note here immediately is that the many judge successfully because they have achieved a certain kind of unity, a man united not only in a physical sense, but also psychologically.

Aristotle's argument for the potential superiority of the multitude continues to preoccupy contemporary political theorists, including Jeremy Waldron, David Estlund, Malcolm Bull and Daniela Cammack, and it has been drawn upon for defences of democracy on both epistemic and what we might call "virtue amplifying" grounds. ${ }^{37}$ But, in their analyses, modern commentators have barely discussed the implications of this "man" metaphor, despite its suggestive associations. ${ }^{38}$ Indeed, as Cammack has pointed out, some Straussians have dismissed this metaphor as "monstrous" and thus clearly ironic. ${ }^{39}$ (That the irony in fact lies in monstrosity being the grounds for dismissal rather than further reflection will become clear when we look to the early modern interpretations of this passage; Hobbes was not alone in seeing that monstrosity can be a persuasive mark of power.) However, Aristotle's "man" metaphor is striking for four reasons.

We should first note the matter of Aristotle's collective man. It is made up of men that have at least some portion of arete, moral virtue, like courage, justice and moderation. ${ }^{40}$ They also have some phronesis, practical judgment. That Aristotle names phronesis as one of the virtues brought together in this man has particularly important implications: in Book Three Chapter Four of the Politics he argues that phronesis is the only virtue unique to a ruler; it is a virtue both developed and exercised when ruling. The collected man, then, is made up of humans who have some capacity for rule in themselves and it is an agent who unites political judgment. Secondly, and relatedly, the individuals who make up the man also contribute their physical capacities - the man has "many feet and hands" - and so too he has the collected physical strength of the multitude.

Thirdly, the effect of this coming together is not simply the creation of an entity that is physically stronger than any single individual, but one which also exhibits a form of mental unity: the multitude "become one" with regard to "character and thought." It is a unity of minds as well as bodies. ${ }^{41}$ And it is the fact of this unity that makes the multitude-as-man a better judge ultimately than any one man might be 
singly; being made into a collective is transformative for the individuals of the multitude; their capacities are amplified and they are rendered more than the sum of their parts. ${ }^{42}$ The body politic understood as a single man transcends in its capacities even the aggregated capabilities of its individual members.

Finally, Aristotle's "man made of the multitude" not only transcends the aggregated capacities of the individuals who constitute him (who, we remember, are not all unqualifiedly "good" men themselves), but also qualifies as "better" than the "best" but few. We might then further suggest that a democracy at its best shares features with an idealised monarchy. ${ }^{43}$ Though it remains unremarked, it is notable that these associations are suggested by Aristotle himself who, in a discussion of monarchy, notes that

an individual ruler, if he has been well educated by law, gives good decisions; but he has only one pair of eyes and ears, one pair of feet and hands, and it would be a paradox if he had better vision in judgement and action than many men with many pairs. Monarchical rulers, as we see even in our own times, appoint large numbers of men to be their eyes and ears, hands and feet. ${ }^{44}$

Good monarchies need many hands and feet; good democracies make a man with many hands and feet. At its best, democracy resolves the deficiencies of monarchy, but only when it has first made a monarch-like unity. Is it possible, then, that the ideal monarch in fact lies in the man made by the multitude?

These are all points raised in this key passage about Aristotle's democratic body politic, but at this point I should address a possible objection to the very use of the word "body politic" to describe the collected multitude. It is justified, I think, on the grounds that this passage is precisely a discussion of the location of sovereignty and, therefore, within Aristotle's own framework, a discussion of the identity of the polis. The multitude here are the citizen-body and, on Aristotle's theory of the city, the city (polis)—or, in early modern terms, the body politic - just is the constitution (politeia), and the constitution is itself the order of the citizen-body (politeuma), especially the sovereign part. ${ }^{45}$ I read this passage as informative not only for thinking about how good decisions come to be made in democracies but also for thinking about the very nature of the democratic body politic itself.

Read against this account in Book Three, it becomes clearer why Vettori might have described the extreme democratic body politic as one man in his commentary. He saw that the discussion of democracy in Book Four was sequential on this account. In Book Four, Aristotle describes how the people becomes a monarch, aims at sole power, and "becomes like a master." 46 There the collected multitude transform from monarch to tyrant. ${ }^{47}$ In this passage, Aristotle is showing the dark side not simply of extreme democracy but of this unity of the multitude. ${ }^{48}$ It was to prove a richly suggestive moment for his early modern readers.

\section{Reading Aristotle before Democracy}

Early modern authors were more than willing to grapple with the theoretical and imaginative puzzles presented by Aristotle's discussions of democracy. Certainly there were some who eradicated entirely the possibility that popular sovereignty might be a preferable form of government. ${ }^{49}$ But many of the most widely printed commentaries on the Politics engage with Aristotle on the nature of democracy and the sovereignty of the multitude. Indeed, with regard to the passage in question, 
some commentators offer readings that support modern (and what we think of as novel) interpretations of the text. ${ }^{50}$ When we consider that such interpretations are often used as the basis for rethinking aspects of our own conception of democracy, this alone gives us reason to return to this long philosophical tradition of reading the Politics. ${ }^{51}$

The medieval and early modern commentaries on Aristotle's Politics offer three principal ways of thinking about the passage in Book Three Chapter Eleven, and in particular, about the idea that democracy is a constitution whereby the multitude make a body politic to be understood as one man. ${ }^{52}$ The first approach is to think of the man as a perfect, human, ruling agent. We get some hint of this interpretation in the very first Latin commentary on the Politics by Albert the Great (d. 1280). Albert was working from William of Moerbeke's recently completed translation from the Greek, and for this reason his interpretations were often highly literal: he sought to bring basic sense to what was, thanks to Moerbeke's penchant for transliteration, a deeply confusing text. When glossing Moerbeke's somewhat muddled Latin- "et fieri congregatorum quasi unum hominem multitudinem multorum pedum et multarum manuum"-Albert comments simply that, according to Aristotle, "the whole multitude becomes like one man." ${ }^{53}$ Unlike some modern readers, Albert does not seem anxious about the apparent monstrosity of the man's many-hands; he simply removes all reference to it. Indeed, later in his comment Albert suggests that "those things, which in the people have been scattered, are ... united and collected in one perfect man." 54

This idea of the multitude who make themselves into a perfect ruler is developed by Peter of Auvergne (1240-1304), who was responsible for the posthumous continuation of Thomas Aquinas's (1225-1274) exposition of the Politics. To Peter, "if there are many individuals and each one of them has a certain amount of virtue and prudence-then when they come together into one they make up a unity that is great and virtuous." ${ }^{55} \mathrm{He}$ goes on to note that

when all come together, they are turned into a single man, as it were, perfect in understanding (in terms of the intellectual virtues) and perfect in appetite (in terms of the moral virtues). ${ }^{56}$

The implication here is clear: on an Aristotelian model, perfect virtue necessarily includes practical wisdom, the virtue Aristotle had argued is unique to the ruler. ${ }^{57}$ If we read this thought in light of Aristotle's argument that, if ever faced with a man of perfect virtue, all we can do is to submit "absolutely" ${ }^{58}$ we might infer that, on Peter's account, the multitude have made a man of which they are at once constituted and to whom they should, according to the logic of Aristotle's own text, render themselves subject absolutely. From their imperfect stuff, they have made the perfect ruler.

The second prominent way of reading this passage takes seriously the idea that the man of the multitude is many-limbed in a physical sense: that he visually embodies the amalgamated many. Aristotle is read here as if he were conjuring a mythical entity. The Florentine Donato Acciaiuoli (1429-1478), operating with the benefit of Leonardo Bruni's (1370-1444) revised translation of 1437, interprets Aristotle's passage with reference to figures from Virgil and Ovid. "If one man could be made out of many," he writes, "that man would have many feet and many hands, as Briareus and Argus in the stories of the poets, and it could carry out more things than a single man." ${ }^{59}$ This might seem obtuse or literal of Acciaiuoli; but his allusion to Argus in particular is suggestive. Argus "panoptes" was the many-eyed monster ordered by Hera to guard Io, and his multiple eyes, some of which were said always 
to be awake, ensured his vigilance as a guardian. He was also, in this context, an agent of the queen of the Gods. The multitude here do certainly make a monster but, as Acciaiuoli saw so clearly, monstrosity was not at odds with sovereignty and, in this case, divine sovereignty. The democratic body politic here is presented as vigilant, always awake, but also as a mythical character whose existing associations could be politically significant (a commonwealth perceived as watchful may be a commonwealth with less need to watch on).

Associations with monstrosity and fable were applied even more directly to this passage by Vettori. Rather than the myths of Briareus or Argus, in his exposition of this passage Vettori compares the man made of the multitude to Geryon, a threebodied monster killed by Hercules in the course of his last three labours. ${ }^{60}$ The likely source for Vettori's knowledge of Geryon is the Aeneid. Most Renaissance readers of this text would have encountered it with at least one attendant commentary, the most popular being that of the fourth-century grammarian Maurus Servius Honoratus. Geryon, Servius explains, was both a monster and the "King of Spain." ${ }_{1}$ Once again, then, we see this moment glossed not only with fable but specifically with fable that suggests hybridity: the creature made by the multitude participates in sovereignty, rule, and monstrosity.

Vettori was well aware that this monstrous comparison could be read as dismissive, but he pre-empted the modern Straussian response. A classical version of their position in fact came from Horace, who, Vettori noted, suggested that Aristotle had meant us to understand this man as a monster and so to dismiss his arguments for the potential superiority of democratic rule. ${ }^{62}$ But Vettori shared neither Horace's suspicions nor his interpretation. He thought that the argument that "the multitude should rather have the greatest power in the city, than the best men ... is worthy of recognition, and is one not suddenly to be ripped apart as vain and false, since it perhaps is rather close to the truth." 63 He then detailed what happens to the multitude, so long as they have some "speck" of prudence:

what we see happen in the parts and members of the body, when in a remarkable manner it is fused together and grows from such a multitude of separate entities, [is that] in wondrous fashion they are able to grow as one. We ought to imagine the same thing happens regarding customs and reason, not forgetting the virtues, which exist in them with the result that these too grow proportionately. However, we cannot so easily conceive of the growth of the mind as we can put before our eyes the physical growth of the body. ${ }^{64}$

This is a significant moment in the history of reading Aristotle's passage. To understand properly the metaphor of the multitude "becoming one man," Vettori says, we might have to step outside of everyday political categories and into the imaginative language of fable. And Vettori tells us why: to conceive of a unity amongst things which we know are, in one important sense, separate is a complex imaginative task. To think of it according to the physical growth of the body helps us to see this process (as he says, to put it before our eyes) and thus gives us a way to figure the extent of the unity Aristotle describes (of minds as well as bodies). This approach is not surprising, given Vettori's humanist credentials, as he is clearly applying to this passage dictates common to classical theories of rhetoric and representation, in particular the demand to make abstract concepts present with metaphors that appeal to sight. As Aristotle himself had said, the most effective speech "sets things before the eyes." 65 Early modern authors found the associations of myth and metaphor, and other "imaginative" means of embodying abstractions, a quite natural means of communicating political ideas. But more specifically in this 
case, myth became the means by which the relations between and the features of a united multitude came to be understood.

A third significant and significantly different interpretation of this passage came from the Oxford philosopher John Case (c. 1540-1600) in his widely printed Sphaera civitatis (1588) or Sphere of the Commonwealth. In an unusual move, Case begins his commentary on Book Three of the Politics by expressing the explicit aim to align Aristotle's theory with contemporary politics, which in his case meant the Elizabethan monarchy. He announces that he will take Aristotle, turn him into a supporter of England and prove (against the grain of Aristotle's own argument in that Book) that monarchy is in fact the best constitution. ${ }^{66}$ Indeed, he also suggests that there is an esoteric dimension to Aristotle's own argument for the superiority of the multitude, one which Aristotle meant some readers to see and one which Case himself would now reveal clearly: the demands of his political context meant, so Case argues, that Aristotle was forced to laud democracy; but what appears to be an argument in favour of the multitude is in fact one meant to support monarchy. For this reason, and for the arguments he uses to reach such a conclusion, Case's is one of the most striking readings of this passage in the Aristotelian commentary tradition.

To the question of whether the multitude can ever rule better than the few best men, Case allows that there are clear benefits to collective decision-making by the multitude: "there is a great power and illumination" within them, he says, and they can indeed be considered better not "as single individuals, but instead as a universal collective" [collectim universi]. ${ }^{67}$ Case, then, interprets Aristotle's metaphor with conceptual categories drawn not from the Aristotelian tradition, but from the Roman legal language of corporation theory: the multitude must be considered as a universitas not singuli for their coherence to be comprehensible and for their superiority to hold. ${ }^{68}$ They are, he says - now combining this corporate idiom with the mythological idiom familiar from previous commentators-a "universal man, who has many eyes, Argus-like, many hands and numerous other parts, Briareuslike, which collected parts "make the people greater in strength, more capable in its works, and wiser in the virtues of its mind." ${ }^{6}$ He suggests, as many commentators have since, that Aristotle is here praising the aggregated capacities of a multitude who cooperate together and act as a single agent.

Were the analysis left here, it would surely seem that Case was reading Aristotle in line with contemporary monarchomach or republican theories of the body politic. Many of these shared a genetic account of the commonwealth wherein the multitude constituted itself as a "people," a universitas, then able to appoint for itself a governor should it wish (and, of course, able to rescind that appointment should the governor misbehave). But in fact his analysis moved in a very different direction. Having praised this vision of the democratic "universal man," Case goes on to undermine it. What Aristotle offers, he suggests, in this idea of a democratic body politic, is merely a multitude held together by consensus, and not in fact a united multitude. What reason do we have, he asks, to think that this "collective" or "man" made up of the people would truly hold together? "Where" he asks "is that bundle of weapons and citizens which the sons of Scylurus could not break? This unanimity of the bees is most rare, the faithful consensus of citizens is most rare." 70 Scylurus was the epitome of the Renaissance idea of "concord," often pictured in iconographical representations of that concept. ${ }^{71}$ As István Hont has pointed out, here Case "prefigured Hobbes's attack on concord when he argued that consensus was no secure foundation for durable political community."72

It is at this point, with this doubt regarding the coherence of the democratic body politic fresh in the minds of his readers, that Case makes good on his promise to 
reveal Aristotle as a secret supporter of monarchy. Rather than continue with a discussion of the good democracy, Case raises what he suggests is the true underlying question of these passages in the Politics: whether or not monarchy is the best constitution of the commonwealth. That is, he reconfigures a discussion of democracy into a discussion of monarchy. And it is here that he outlines how it is that the multitude might achieve true unity. The multitude, he argues, cannot be held together unless through a king: it is the monarch who gives the body politic unity. As he puts it, "the parts of the commonwealth live in the king"73 and Case is explicit that this is to be understood not as concord or consensus, but as a form of "union": "there is in one," he writes, "a union of many." 74 It is union, on Case's analysis, that forms the proper basis of a body politic, and a single, uniting figureand on Case's vision, always a monarch - that provides union.

To insist that the city is a union was to strike right at the heart of early modern political metaphysics. ${ }^{75}$ To explain the relationship between prince and body politic, we again find Case stepping beyond categories most familiar to the Aristotelian tradition and borrowing from the conceptual resources of Roman Law. The union of the entire commonwealth is explained via "personation." The king is to be conceived "not as one small man but as the person of the whole commonwealth." 76 The monarch "bears the person of the entire commonwealth." Case presents the monarch here as the solution to the problem of unity; the implication appears to be that the ruler is bearing the person of something that can maintain a collective existence outside of that ruler. This is not systematically theorised by Case, but he did elsewhere further allude to this mutual dependency between sovereign and commonwealth when he claimed that "the prince is the soul of the commonwealth." 77 This, of course, is the same broad Aristotelian framing that Hobbes would use to describe the same relationship in the Introduction to Leviathan. That is, Hobbes would come to share with an author like Case the idea that there is a sense in which the sovereign is the formal cause of the commonwealth: that without which there simply can be no commonwealth. ${ }^{78} \mathrm{He}$ would also share the thought that the sovereign is he who bears the person of the commonwealth.

In a further striking move, Case transposes the characteristics that had heretofore been associated with the democratic body politic onto a discussion of the monarch. As we saw above, these echoes are there in Book Three Chapter Sixteen of the Politics itself. But in describing the monarch who bears the person of the body politic, Case used the mythological language associated by Donato Acciaiuoli with the good democracy. It is now the monarch who, he says, "possesses many eyes and many hands," is "all-seeing like Argus and all-comprehending like Briareus." "For the king has wise men as his counsellors, the king has countless inferior magistrates, and finally, the king has the people's hands and feet." 79 Case attributes to the monarch the features of the united multitude and its collected strength. It is the monarch who is now associated with the very idioms and images that had been developed in discussions of the democratic body politic. To put the point differently, the monarch takes on the part of the united multitude; in a certain way, he becomes the man of the collected multitude.

What, then, should we infer from Case's interpretation? It is striking that he transformed a discussion of democracy into a meditation on the very metaphysics of the city. The resulting body politic was both a man of fable and a civil person that needed to be represented to achieve unity, and so too, we must imagine, to be able to act. And whilst these moves are under-theorised by Case, it is hard to ignore that Hobbes would also come to employ a metaphysic of "personation" in his own attempt to explain how we might understand the unity of otherwise disparate individuals; and he too would insist that without a sovereign representative, there was no 
commonwealth of which to speak. That is to say, John Case's reflection on democracy - a reflection which we know was on the inventory of books Hobbes himself made of the Hardwick library - can be read as a resource for two conceptual issues that would become central to Hobbes's thinking about the commonwealth: the distinction between union and concord, and the idea that the union of the body politic depended upon a monarch (or sovereign) personating - or representing - the commonwealth. The demand both for a conception of the city as some form of union, and the need for personation in describing this is present in all three versions of Hobbes's political theory. ${ }^{80}$ One key difference between the two authors was that Hobbes thought of the uniting figure as a sovereign understood generally, so allowing that the sovereign could be either a single human or a group. Case, on the other hand, made the more limited claim that this uniting role needs to be played specifically by a monarch. Nonetheless, if we read Hobbes through an author like Case, we see that questions of democracy, the unity of the city, and the coherence of the multitude had, by the late sixteenth century, already become mutually implicated.

\section{Aristotle’s Democracy and Hobbes's Body Politic}

How, then, should these readings of the democratic body politic affect our interpretations of Hobbes's political theory? In offering these concluding thoughts, I do not wish to overstate the confluences between the Aristotelian meditations that I have traced and Hobbes's account of the instituted body politic. There is much that separates them, not least the fact that in each of his three major works of political theory Hobbes was deploying a nuanced juridical language alien to most of the Aristotelian tradition. ${ }^{81}$ Indeed, the sheer conceptual sophistication of Hobbes's theory of the body politic might lead us to conclude that it is the limits of the comparison that are the most informative. And yet the images offered both by Aristotle and his early modern commentators of a democratic multitude forming a body politic, understood conjunctively as a single man and a unity which shared features with an idealised monarchy, are revealing not simply for what they share with Hobbes's own eventual vision. This historical background also throws into sharper relief aspects of Hobbes's approach to civil philosophy that are less commonly discussed and, indeed, features of early modern reflections on the body politic that have been hidden from view.

One of the most striking features of some of these Aristotelian accounts of the man of the multitude is that the question of how we understand the body politic is answered in terms of how we visualise the collected multitude. As has long been noted, Hobbes too was deeply concerned with how men saw the state. The issue of visualisation is related to his anxiety that readers came to understand the body politic as a union of men, and not as men in concord, and that they would grasp his concept of unity. It is conventionally accepted that his concern men understand unity manifested in his distinctive insistence on science-deductive reasoning from fixed definitions - as the means for demonstrating to his reader the true nature of the commonwealth. But what is less commonly discussed is the extent to which Hobbes believed that appealing to a series of rationally deductive arguments was insufficient for effecting true understanding in readers. He believed not only that we should be able to give a rational account of the state's form and its genesis, but that readers should be able to see it. (Perhaps Hobbes himself saw that something a little 
spooky happens in his own 'rational' account of the process by which the multitude appoint a sovereign who creates their unity and is then also said to represent it.) Both Hobbes, and the Aristotelian authors we have looked at here, worked on the assumption that political theory must pay special attention to how its audience imagines the body politic. For Hobbes, a political theory must show both why the state is all powerful, and what an all-powerful state looks like. This leaves us with a Hobbes attempting to induce his readers to imagine political relations and not simply a Hobbes, as he is so commonly styled, concerned with a set of conclusions to which he was attempting to force them to submit. ${ }^{84}$

This concern with how readers saw the commonwealth had a partial basis in Hobbes's insight that humans are sophisticatedly imaginative animals. This is another often-underestimated aspect of his political theory and yet it underpins many of his central claims, not least his theory of personation or representation, which rests on the assumption that we are animals that can take one thing for another. His psychology emphasized the human mind as the place that registers and manipulates images - the images that provide the prompt for all of our voluntary action. Hobbes thought that the images we held in our minds were directly related to the decisions we made about how to act in the world. He also came to think that some of the most "marvellous effects to the benefite of mankinde" came about when "fancy"-by which he meant the imagination-"traced the ways of true Philosophy." 85 Fancy has a central role to play in promoting true belief. Where Hobbes certainly believed that science changes how those with it saw the worldindeed, he explicitly referred to it as akin to having a new lens ${ }^{86}$ - he also thought that its results sometimes needed to be communicated to an audience using means beyond that of deductive argument. The philosopher had also to attend to the tools of the imagination. Not least because, for Hobbes, to understand something was to be able to call to mind the right images of what you claimed to understand.

It is no novel insight that Hobbes was preoccupied with the relationship between seeing and understanding and, in particular, with the role that fancy might play in helping his audience to appreciate the unity of the body politic. ${ }^{87}$ The frontispiece of Leviathan is by far the most famous example of Hobbes's attempt to use "visual strategies" to represent some of the most complex features of his theory of the commonwealth: that the sovereign is the form of the commonwealth, and that which gives unity to an otherwise disunited multitude. As Noel Malcolm has revealed, it is likely that Hobbes's acquaintance with the newly fashionable dioptric anamorphosis, produced by lenses which brought otherwise disparate images into a single unity, lay behind the form of this notorious image of the artificial man of the multitude. ${ }^{88}$ Hobbes was inspired by a new technology which allowed real entities to appear united, in order to illustrate his new political theory which itself required a fundamental shift in how people saw the state.

Language was the other human invention that Hobbes thought could shape the imaginations of his readers. ${ }^{89}$ In the same place that he makes his fullest statements about the relationship between fancy and philosophy, he points out that words can have the same effect on the imagination of a reader as could "the artificiall cutting of glass." 90 And so, Hobbes's concern to engage with the imaginative dimension of his readers' comprehension of the body extended to the very words he chose to describe the genesis of the commonwealth. In the "Preface to the readers" of De cive, Hobbes famously suggests that those who want to understand a commonwealth must "view it as if taken apart". The purpose of of this, Hobbes tells us is to understand "how men who want to grow together [coalescere] must be connected [componi]."91

The language here is striking for at least two reasons. First, to have the process of the formation of a commonwealth described in terms of men seeking to "grow 
together" emphasises both the imaginative and the organic dimensions of his account of the body politic. Men are to imagine their unity as an organic one, even if the means to achieve this are artificial. ${ }^{92}$ This is apparent from the juxtaposition of coalescere and componere: in Thomas Thomas's Latin-English dictionary of 1587, we find coalesco defined as "to grow together . . . to increase" alongside the idiomatic phrase "to grow into or to become one body or people." Compono, on the other hand, is defined as "to put or ioyne together," "to set in order" and, even more suggestively, "to build and erect." Even as men must use artifice to build a commonwealth for themselves, they are to think of it as aping a process of natural growth and increase..$^{93}$ This is more than an example of the adage that art should imitate nature which Hobbes references in the opening sentence of Leviathan's Introduction. The point here seems to be that art might transform nature: it is possible that when reading these lines Hobbes's readers may have thought of the fashionable early modern practice of grafting, the process whereby distinct organic entities were artificially combined to create an altogether new entity, which literally grew together in a new unity.

Secondly, that Hobbes should describe the aim of men forming a state as "growing together" is striking precisely because it is not the austere, technical language of a strictly juridical analysis of the nature of men's association. Hobbes moves between different registers in his accounts of the formation of the state, concerned as he is to provide readers not only with an account of their relationship to the sovereign, but also with an image of their relationships to one another. Where the former could be explained through the language of representation, and in Leviathan, of authorisation, which explains why we own the sovereign's actions, Hobbes clearly thought and repeatedly claimed that there was a place for organic imagery in explaining how subjects should think of their relationship to each other. Hobbes knew that the kind of total unity he demanded was unusual - he knew too that it was not something that the standard juridical language could quite capture. This is perhaps why, despite so often relying upon the language of pure artifice he did not spurn the language of nature.

If the formation of the commonwealth involves men seeing themselves as having grown together in some fundamental sense, what is the mechanism for achieving this? It is at this point that we might think that the figurative associations of democracy come to matter. Democracy, as we have seen, was associated in the Aristotelian tradition not only with the growth of otherwise disconnected individuals into a united man, but also with the "increase," the achievement of more than the sum of their initial parts, suggested by Hobbes's word coalesco. We have also seen, in the case of Vettori, the very recognition that this growing together is a process that is particularly difficult to communicate precisely because it is not a physical coming-together but a psychological one. In this, and to varying degrees, Vettori and Hobbes shared a solution: each provided readers with a mythic comparison that relied upon the operation of the imagination-for Vettori, Geryon; for Hobbes, the artificial man, or, indeed, the Leviathan. ${ }^{94}$ And perhaps Hobbes also took from the Aristotelian tradition the insight that democracy was itself associated with producing the kind of unity he wished to convince readers was an essential feature of all commonwealths. Democracy here came to be understood as the mechanism by which a unity of minds could be achieved. Indeed, what distinguishes the Aristotelian democratic account from the other examples of bodies politic that resemble Hobbes's is precisely the fact that at the foundation of this unity was democracy. ${ }^{95}$ The question of Hobbes's relationship to democracy is often taken as a question of Hobbes's political allegiance, or his normative assessment of democracy. But this can obscure the story about what conceptions of democracy might have 
given Hobbes imaginatively; that is, what it helped him to place before his readers' eyes.

This history has implications for how we think about the puzzle of the democratic founding of Hobbes's commonwealths by institution. One of the main objections to Tuck's original argument was the well-made case that democracy is only foundational for Hobbes in his discussions of commonwealths "by institution." 96 This is no doubt right and should moderate some scholars' claims for a "democratic Hobbes." But just as we need to note that democracy is not foundational for all commonwealths, so do we need to be careful of passing over its place in Hobbes's thinking too quickly, especially given its overt role in the Elements and De cive and its tacit presence in Leviathan. Even if we were to concede that commonwealths by acquisition were the "fundamental case", historically speaking, for Hobbes, it does not follow from this that because the account Hobbes gives of commonwealths by institution is "purely hypothetical" it is therefore "subordinate" to the theory of commonwealths by acquisition. ${ }^{97}$

Indeed, it is not at all clear, as it has been claimed, that Hobbes thought that bodies politic which arise "from the consent of a democratic assembly [are] like a divine mystery that cannot properly be considered within philosophy" and so that the "real" focus of civil philosophy ought to be bodies politic that arise from compulsion. ${ }^{98}$ Kinch Hoekstra has argued that one way that we can see the difference in the importance Hobbes gives to commonwealths by institution as opposed to commonwealths by acquisition is by looking at a comment of his in The Elements of Law. There Hobbes says "there be two ways of erecting a body politic; one by arbitrary institution of many men assembled together, which is like a creation out of nothing by human wit; the other by compulsion, which is as it were a generation thereof out of natural force." Hoekstra reads this as Hobbes saying that it is only commonwealths by institution that are created "out of nothing" and therefore are to be considered as incomprehensible by philosophy. However, it seems that the best way of making sense of the word "thereof" in the final clause is to read it as referring to "out of nothing". Thus Hobbes here in fact claims that bodies politic made by arbitrary institution are creations "out of nothing" by human wit, just as bodies politic by compulsion are also creations "out of nothing" by natural force. ${ }^{99}$ This being so, we surely must continue to ask what kind of role a purely hypothetical account of the formation of the body politic plays in Hobbes's theory, and, further to this, why it is he places democracy at its foundation, as he does explicitly in the Elements and De cive.

One possible answer is that Hobbes knew that many of his own readers would be aware of that tradition of thought wherein, in the words of the 1598 translation of Aristotle's Politics, "it is possible, that a great multitude . . . being assembled together may be better ... for when they are many ... united together, the multitude becomes as it were one man . . . those excellencies which were divided before, are collected and combined into one." 100 Democracy could not only be a first step in providing the kind of unified body politic Hobbes wanted, but it was associated precisely with the way Hobbes wanted to figure the unity of that body politic: as an entity made up of many but with a single will. In communicating this unity Hobbes might well have employed the established vocabulary and the illustrative "fancy" of democracy's most influential theorist.

This leads to a concluding point about the place of commentary in this account and in the history of political thought more broadly. The fact that commentary is rarely looked to as a resource is possibly a reflection of our own biases about what it means to do political philosophy. ${ }^{101}$ It is no doubt also a mark of the resilience of Enlightenment criticisms of the practice. But for the history of political thought to 
dismiss the commentary tradition is to also miss the philosophical and imaginative resources contained within it. The considerable creativity of these texts-wherein metaphor, myth and poetry operate as hermeneutic and philosophical devices-offer ways of thinking about political philosophy where the literary is not opposed to the analytical. Early modern commentators were certainly alert to what has been called the "further task" of philosophy "not to gain a better insight into reality, but, analogously to poetry, to stretch our imagination and our language and thus to help create a new world for living in." 102 In this, perhaps, there is still something to learn from early modernity. Certainly we should not continue to ignore a tradition whose longevity and influence can only (and at the very least) aid our understanding of the nature and range of early modern political thought, but might also aid our own attempts to understand Aristotle — and indeed Hobbes - today.

\section{Notes}

1. The literature on the re-emergence of democracy (and democratic rhetoric) in nineteenth-century Europe is vast; for an account of this revival in late eighteenth-century and early nineteenth-century France, in comparison to democracy's "first coming" in Greece, see J. Dunn, Setting the People Free: The Story of Democracy (London: Atlantic, 2006).

2. F. M. Coleman, Hobbes and America: Exploring the Constitutional Foundations (Toronto: University of Toronto Press, 1977), 3: "Hobbes is the true ancestor of constitutional liberal democracy"; J. R. Martel, Subverting the Leviathan: Reading Thomas Hobbes as a Radical Democrat (New York: Columbia University Press, 2007). For Hobbes as the founder of a strand of modern democratic theory, see G. Borrelli, "Hobbes e la teoria moderna della democrazia Rappresentanza assoluta e scambio politico," Trimestre 24 (1991): 243-63 and 259; A Matheron, "The Theoretical Function of Democracy in Spinoza and Hobbes," in The New Spinoza, ed. W. Montag and T. Stolze (Minneapolis: University of Minnesota Press, 1998).

3. R. Tuck, "Hobbes and Democracy," in Rethinking the Foundations of Modern Political Thought, ed. A. Brett and J. Tully (Cambridge: Cambridge University Press, 2006), 171-90, 185-90.

4. See K. Hoekstra, "A Lion in the House," in Brett and Tully, Rethinking the Foundations, 191-218; and Q. Skinner, "Surveying the Foundations: A Retrospect and Reassessment," in Brett and Tully, Rethinking the Foundations, 236-61, esp. 251-56.

5. Tuck, "Hobbes and Democracy," 172.

6. See J. Waldron, "The Wisdom of the Multitude," Political Theory 23 (1995): 56384; and D. Cammack, "Aristotle on the Virtue of the Multitude," Political Theory 41 (2013): 175-202.

7. The counter-argument is presented in Hoekstra, "A Lion in the House," 207-13.

8. He says explicitly in Chapter 20 of the Elements that he is interested in revealing the "nature of a body politic." T. Hobbes, Human Nature and De Corpore Politico (Oxford: Oxford University Press, 1999), 109. Henceforth Elements.

9. See especially the critique of extreme unity in Plato's Republic in Aristotle, The Politics, ed. T. J. Saunders, trans. T. A. Sinclair (London: Penguin Classics, 1992), 1260b27-1264b25.

10. As Tuck points out, in De cive the term consensio is used in the body of the text, and concordia in the marginal notes and chapter summaries.

11. Hobbes, Elements, 106. 
12. Hobbes, Elements, 173-74. My emphasis.

13. See A. Brett, Liberty Right and Nature: Individual Rights in Later Scholastic Thought (Cambridge: Cambridge University Press, 1997), chap. 6.

14. The idea of the state as an artificial body is present in De cive via the metaphor of the clock, but is only developed as an explicit feature of the theory in Leviathan, where the state is described as an artificial man.

15. Hobbes, Elements, 107, my emphasis.

16. T. Hobbes, On the Citizen, ed. R. Tuck and M. Silverthorne (Cambridge: Cambridge University Press, 2005), 5.9.

17. There is a slide, I think, in Hobbes's use of the word "person" in relation to the state; he clearly describes the body politic as a person in the Elements but by Leviathan, it is hard to see how the claim that the state is a person fits the theory of persons Hobbes outlines at the start of Chapter 16. The state is not, in Leviathan, an "artificial person" though it is an artificial man. See Q. Skinner, 'Hobbes and the Purely Artificial Person of the State' in his Visions of Politics, vol. 3: Hobbes and Civil Science (Cambridge: Cambridge University Press, 2002), 177208. For the argument that we should understand the state as a 'person by fiction' see D. Runciman, "What Kind of Person Is Hobbes's State? A Reply to Skinner" Journal of Political Philosophy 8 (2000): 268-78.

18. Hobbes, Elements, 109.

19. Tuck, "Hobbes and Democracy," 174.

20. Tuck is also interested in how this Aristotelian account of extreme democracy is associated with the history of Republican Rome, but his observations, while also suggestive, are not relevant to my account here.

21. Aristotle, Politics, 1292a7. I have modified Sinclair's translation, which reads "one person composed of many," for two reasons: first, the Greek does not stipulate a noun with the word "one" but as it is masculine the word "man" could easily be understood, yet as we shall see, it is vital to Tuck's case that Pier Vettori innovates by supplying the noun "homo" in this instance. It seems important then to note that no such word was in the Greek. Furthermore, the language of "persons" was loaded with connotations of legal "personation" in the sixteenth and seventeenth centuries, which as we shall also see, was a term only then applied to this particular passage.

22. Aristotle says that "if you were to say that such a democracy is not a constitution at all, your strictures would seem to be perfectly right . . . so if democracy is one of the constitutions, it is clear that this kind of set-up, where everything is governed by decree, is not a democracy at all, in the real sense." By the "real sense" here, Aristotle means that it is not really a framework of laws, because rule is only according to immediate decree. Aristotle, Politics, $1292 \mathrm{a} 31$.

23. It contrasted with the conventional view of a body politic where "different elements worked together but kept their individuality," where "the ruler was separate from the ruled" and where "the agreement between ruler and ruled which kept the body functioning." Tuck, "Hobbes and democracy," 183.

24. "Narrat in iis civitatibus, in quibus leges nullae, quae frenent impetus multitudinis, fixae sunt, populum paulatim fieri dominum, solumque illic imperare: quid tamen discriminis sit inter ipsum, ac proprie vocatum monarcham, ostendit: ille enim unus mortalis est, qui sui iuris omnia fecit: hic vero iunctus est e multis, tanquam ex omnibus illis mortalibus ex quibus constat populus, simul concretis, unus homo factus." P. Vettori, In VIII libros Aristotelis de optimo statu civitatis (Florence, 1576), 314-15.

25. It should be noted that Tuck in fact sees two key developments in this passage. The first is that through it Vettori becomes the first author in the history of 
political thought to offer the "plain statement" that a people is "one man"; this thus "must have been a source" for Hobbes's conception of monarchy as a constitution wherein "the subjects are the crowd, and (paradoxically) the King is the people." Kinch Hoekstra has already shown that there are many historical precedents for such a claim, but it is also worth noting that it is not clear Vettori was in fact saying that "a people is formed by all coming together and making a man" as Tuck suggests in his own translation. As it is unclear how the Latin could bear that sense I have focused in this account on the second of Tuck's claims for the significance of Vettori's intervention. "Hobbes and democracy," 183: "Hobbes clearly referred to Aristotle's observation that (in Vettori's translation) the tyrannical democracy was where the princeps populus fit'; and p. 181, where Tuck suggests Vettori "must have been a source of Hobbes's thinking on the subject." For Hobbes and the phrase "the King is the people," see Hobbes, On the Citizen, 12.8.

26. Tuck, "Hobbes and democracy," 183.

27. Hobbes, On the Citizen, 7.5.

28. Ibid.

29. On Tuck's reading, the anatomical unity made by an extreme democracy is unique to it, made possible only by features it does not share with other kinds of democracy discussed by Aristotle. For Tuck, the people "become a monarch" (in Aristotle's phrase) precisely because they have been ruling as tyrants, through their plebiscita and encouraged by demagogi. These, he suggests, are necessary conditions for the achievement of unity. But this does not stand up to scrutiny of Aristotle's more general discussions of democracy in Book Three of the Politics where we can find Aristotle himself formulating the democratic body politic as a single man (a fact that, as I argue further below, surely explains Vettori's own willingness to use the word "homo" in the Book Four discussion).

30. The Sinclair translation uses the word "aggregate" here; I have chosen "multitude" in line with a number of early modern translators and commentators, not least because "multitude" is such an important category in the early modern political thought we are discussing here. See Aristotle, Politics, 1274b40.

31. Ibid.,1278b9-11. For reservations about the use of the word "sovereign" to translate kurios and ta kurion here, see M. H. Hansen, The Athenian Assembly in the Age of Demosthenes (Oxford: Blackwell, 1987), 106. Richard Mulgan has noted that "the most natural English translation of kurios is 'sovereign," though "we must beware of importing modern ideas of sovereignty into our reading of Aristotle." See R. Mulgan, “Aristotle's Sovereign,” Political Studies 18 (1970): 518. Discussions with Melissa Lane have greatly aided my own understanding of these points; for a new and powerful interpretation of popular sovereignty in the Politics see her "Popular Sovereignty as Control of Officeholders: Aristotle on Greek Democracy," in Popular Sovereignty in Historical Perspective, ed. R. Bourke and Q. Skinner (Cambridge: Cambridge University Press, 2016), 52-72.

32. Ibid., 1278b 11-14.

33. Ibid., 1279b18-20.

34. Ibid., 1281 a40.

35. Spoudaios is a difficult word to translate. In the Latin it is usually rendered studiosus and it has connotations of a zeal for virtue and a "soundness" of moral character.

36. Aristotle, Politics, 1281b2-6.

37. Waldron, "The Wisdom of the Multitude," 563-84; D. Estlund, Democratic Authority (Princeton, NJ: Princeton University Press, 2008); M. Bull, "The Limits 
of the Multitude," New Left Review 35 (2005): 19-39; Cammack, "Aristotle on the Virtue of the Multitude," 175-202.

38. Cammack, e.g., while offering by far the most nuanced analysis of this passage to date, refers to the "man" only in passing and not on its own terms. Cammack, "Virtue of the Multitude," 184.

39. As discussed in Cammack, "Virtue of the Multitude," 178. For the Straussian dismissal, see D. Winthrop, "Aristotle on Participatory Democracy," Polity 11 (1978): 159; T. Lindsay, "Aristotle's Qualified Defense of Democracy through 'Political Mixing'," Journal of Politics 54 (1992): 101-19.

40. See Cammack, "Virtue of the Multitude," 184.

41. This is precisely the kind of unity that interests Hobbes, according to Tuck, and the kind of unity he argues can only be found in an extreme democracy.

42. For this point about amplification (as opposed to aggregation alone) which I find wholly persuasive, see Cammack, "Virtue of the Multitude," esp. p. 187. For this idea in a slightly different form, see Waldron, "Wisdom of the Multitude," 561-71.

43. If tyrants become more likely to maintain rule the more like kings they become, do democracies flourish the more like virtuous monarchies they become? From this perspective, Aristotle's best democracy begins to look a little like an idealised monarchy. Cf Tuck: "Hobbes had a specific and interesting theory of democracy, even though it may (to some extent) have been a by-product of his desire to defend an idealised monarchy." Tuck, "Hobbes and Democracy," 171.

44. Aristotle, Politics, 1287b25-30.

45. Ibid., 1278 b9.

46. Ibid., 1292a16-17.

47. The unity Tuck attributes to the Book Four account doesn't seem to hold once we notice that Aristotle's theory of democratic sovereignty seems to suggest that the multitude form themselves into one man. The point of difference comes in how that man rules.

48. The "extreme" democratic man does not have a more obvious connection to Hobbes than the "good" democratic man simply because it rules by decree: as Hoekstra points out, a Hobbesian democracy would "rule by established general nomoi rather than occurrent particular psephismata." Hoekstra, "Lion in the House," 196.

49. See, e.g., [N. de Vaudemont], Quaestiones Johannis Buridani super octo libros Politicorum Aristotelis (Paris, 1513), fol. 39v where the passage from Book Three Chapter Eleven becomes a discussion of the election of the prince.

50. There is insufficient space to go into this here, but early modern readings of Book Three Chapter Eleven tend to support the "virtue amplifying" model presented by Cammack as opposed to the "epistemic" account offered by Waldron.

51. As Cammack has suggested, misreadings of Aristotle past and present have led, however unwittingly, to accounts of democracy that limit the possibilities of mass political activity in ways that Aristotle did not endorse, and "the failure of some of his recent readers to see this may reveal not only a deficiency in the contemporary interpretation of Aristotle but in the contemporary conception of democracy as well." Cammack, "The Virtue of the Multitude," 194.

52. The authors I look at here are some of the most important and creative commentators from the late thirteenth to the late sixteenth centuries, all of whom are recommended for their insights by the Elizabethan philosopher John Case, who wrote a genre-stretching commentary of his own, the Sphaera civitatis, which is looked at in more detail below. Whilst they do not exhaust the list of extant Politics commentaries in early modernity, my aim here is to pick out the most interesting of those contributions for the passage I am concerned with. 
Another story would perhaps emphasize different authors. It's nonetheless my contention that the three approaches I suggest here capture, broadly speaking, the approaches of most commentators on this passage. For Case's full list of suggested commentators, see J. Case, Sphaera civitatis (Oxford, 1588), sig. $\mathbf{\Upsilon} \mid 5^{\mathrm{r}}$. For a comprehensive bibliography of early modern commentaries that includes those on the Politics, see Charles Lohr's exceptionally useful series of articles on "Renaissance Latin Aristotle Commentaries" in Studies in the Renaissance.

53. A literal rendering of Moerbeke's Latin reads: "and to become [of] coming together as if one man the many having many hands and many feet...." For Moerbeke, see Albert the Great, Politicorum Aristotelis, 160. For Albert's comment, see: ibid., 164: "id est, tota multitudo fit quasi unus homo."

54. Ibid.: "quae enim in populo dispersa sunt de similitudine boni, in uno perfecto viro collecta sunt et congregata."

55. Peter of Auvergne, "Commentary and Questions on Book III of Aristotle's Politics (Selections)," in The Cambridge Translations of Medieval Philosophical Texts, ed. A. S. McGrade, J. Kilcullen, and M. Kempshall (Cambridge: Cambridge University Press, 2001), 225.

56. Peter of Auvergne, "Commentary and Questions," 226.

57. Aristotle, Politics, $1277 \mathrm{~b} 26$.

58. Ibid., 1288 a29.

59. D. Acciaiuoli, In Aristotelis libros octos Politicorum commentarii (Venice, 1566), fol. $97^{\mathrm{v}}$. Briareus, the monster with one hundred arms and fifty heads, can be found in Book VI of Virgil's Aeneid. Argus is described by Ovid as having a head with a hundred eyes.

60. See Virgil, The Aeneid, VI-VII. Virgil is not, of course the only source for Geryon. Another account is given in Apollodorus' Library, the first Latin edition of which was published in 1555 by Bendedictus Aegius. Horace mentions Geryon's three bodies in passing in the Odes (II.15) as does Ovid in IX.184 of the Metamorphoses.

61. Servius makes this comment in his commentary on Book VII of the Aeneid: "Geryones rex fuit hispaniae, qui ideo trimembris fingitur, quia tribus insulis praefuit, quae adiacent hispaniae balearicae minori, maiori: et ebusae." See Virgil, Bucolica, Georgica, Aeneis cum Servii commentariis accuratissime emendatis . . . (Venice, 1507), sig. DDDiiiv

62. Vettori, In VIII libros Aristotelis, 230.

63. Ibid., 229: "Oportere autem multitudinem potius summam potestatem in rep. habere, quam optimos viros, eosdem tamen paucos, videri posset hoc pacto: et opinionem sane hanc dignam esse animadversione intelligi, nec subito ut inanem ac falsam explodendam esse, cum fortasse veritati affinis sit."

64. Ibid., 230: "Quod igitur in partibus corporis membrisque contingere [sic] quasi cernimus, ut mirum in modum concretum ex tanta multitudine ipsorum augeatur: idem cogitare debemus usuvenire in moribus ac ratione, nec non virtutibus, quae in ipsis existunt, ut ipsae quoque proportione crescant, sed non tam facile auctum animi complecti mente possumus, ut ponamus nobis ante oculos amplificationem corporis."

65. Aristotle, Rhetoric, trans. W. Rhys Roberts, in The Complete Works of Aristotle, ed. J. Barnes (Princeton, NJ: Princeton University Press, 1995), 1410b34.

66. Case, SC, 251:"Veniam hoc loco peto si Aristotelem faventem Graeciae ad Angliam fovendam pertraham."

67. Case, $S C, 230$.

68. For the uses of this language in Renaissance political thought, see Q. Skinner, "From the person of princes to the person of the state," in Visions of Politics, 3 
vols. (Cambridge: Cambridge University Press, 2002), vol. 2, 368-413, esp. 39192.

69. Case, $S C, 254$.

70. Ibid., 255. Scylurus, on his death-bed, presented his sons with a bundle of javelins and asked them to break it; when they were unable to he removed one "and easily broke them all, thereby teaching the young men that, if they stood together, they would continue strong, but they would be weak if they fell out." Case cites Plutarch in a marginal note, and the description can be found in Plutarch, Moralia, 15 vols., trans. F. C. Babbitt (London: Loeb Classical Library, 1968), vol. III, 27.

71. I. Hont, Jealousy of Trade: International Competition and the Nation-State in Historical Perspective (Cambridge, MA: Belknap Press of Harvard University Press, 2010), 20 34.

72. Ibid.

73. Case, SC, 264: "partes civitatis in rege vivunt."

74. Ibid.: "Est enim in uno multorum unio."

75. A. Brett, Changes of State: Nature and the Limits of the City in Early Modern Natural Law (Princeton, NJ: Princeton University Press, 2011), esp. chap. 5.

76. Case, SC, 267: "Nam regem non ut unum homuncionem, sed ut totius civitatis personam consideramus."

77. Ibid., prologue, n.p.

78. As Noel Malcolm points out, we should not think that Hobbes's use of Aristotelian hylomorphism in his analysis of the commonwealth is in any tension with his criticisms of Aristotelian physics. Where formal causation may be irrelevant for physical science, given Hobbes's insistence that the commonwealth is something we make for ourselves, there is not a problem in using it for such intentional actions. See N. Malcolm, "Hobbes's Science of Politics and his Theory of Science," in Aspects of Hobbes (Oxford: Clarendon Press, 2002), 146-55, 151.

79. Ibid., 266: "rex non solum duos oculos duasque manus habet, sed, ut Argus, videt, et, ut Briareus, comprehendit omnia. Rex enim viros a consilio sapientes habet, rex inferiores magistratus infinitos habet, rex denique populi manus pedesque habet."

80. For Hobbes's use of the language of personation, see P. Pettit, Made with Words, esp. chaps. 4-5.

81. The most notable exception here is the Ferrarese humanist commentator Antonio Montecatini and his juridically informed In politica, hoc est, in civiles libros Aristotelis progymnasmata (Ferrara, 1587).

82. I am grateful to David Runciman for discussion on this point.

83. Skinner, "The Purely Artificial Person of the State," 203-4.

84. My thanks to John Dunn for discussion on this point.

85. T. Hobbes, "Answer to the Preface to Gondibert," in Sir William Davenant's Gondibert, ed. D. F. Gladish (Oxford: Clarendon Press, 1971), 145.

86. R. Tuck "Optics and Sceptics: The Philosophical Foundations of Hobbes' Political Thought," in Conscience and Casuistry in Early Modern Europe, ed. E. Leites (Cambridge: Cambridge University Press, 1988), 234-63. In Leviathan, he describes moral and civil science, for example, as "prospective glasses." See T. Hobbes, Leviathan, ed. N. Malcolm (Oxford: Oxford University Press, 2013), 282.

87. See Q. Skinner, Reason and Rhetoric in the Philosophy of Hobbes (Cambridge: Cambridge University Press, 1996); H. Bredekamp, "Thomas Hobbes's Visual Strategies," in The Cambridge Companion to Hobbes's Leviathan, ed. P. Springborg (Cambridge: Cambridge University Press, 2007), 29-60. N. Malcolm, "The Title Page of Leviathan, Seen in Curious Perspective," in Aspects of Hobbes, 200-28. 
88. When viewed through a dioptric lens, images that appeared disparate to the naked eye would be brought together into a single, coherent image, with no trace of their former separation evident. One famous contemporary example is of a series of portraits of Ottoman Sultans which, when viewed through the lens, form a single portrait of Louis XIV. See Malcolm, "The Title Page of Leviathan."

89. For the implications for his political theory of Hobbes's thought that language is a human invention, see P. Pettit, Made with Words, esp. chaps. 3-7.

90. See the final paragraph of Hobbes's "Answer" to William Davenant's Preface to Gondibert. W. Davenant, Preface, 159.

91. Hobbes, On the Citizen, 10. The Latin here reads: "et quomodo homines inter se componi debeant, qui coalescere volunt, rectè intelligatur." See Hobbes, De cive, ed. H. Warrender (Oxford: Oxford University Press, 1984), 80, my emphasis.

92. This recalls the Introduction to Leviathan, with its allusion to the ubiquitous trope of the imitative relationship between art and nature. We might think of this particular example as another example of what has been called Hobbes's "mechanistic organicism." See D. Runciman, Pluralism and the Personality of the State, 24.

93. Recall Chapter Ten of Leviathan where Hobbes describes "the greatest of humane Powers, is that which is compounded of the Powers of most men, united by consent, in one person." Hobbes, Leviathan, 132.

94. For the relationship of the "artificial man" imagery to mythic traditions, and for the argument that it is a more central metaphor to Hobbes than is the "Leviathan," see H. Bredekamp, "Visual Strategies," 33-35. See too P. Springborg, "Hobbes's Biblical Beasts: Leviathan and Behemoth," Political Theory 23 (1995): 353-75.

95. For example, there are clear echoes in Hobbes's theory of the account found in Asclepius, part of the Codex Hermeticum, of the man-made Gods who illuminate the men who shaped them. For a discussion of this passage from the Asclepius in the context of Hobbes's visual strategies, see Bredekamp, "Visual Strategies," 3335.

96. Hoekstra and Skinner both make this point in Rethinking the Foundations.

97. Hoekstra, "Lion in the House," 207-13.

98. Ibid., 209.

99. Ibid.

100. Aristotle, Politiques, trans. I. D. (London, 1598), 157.

101. Although, of course, it might be suggested that something like a commentary tradition can still be located in contemporary political philosophy, not least in the detailed responses to the philosophy of John Rawls; perhaps there is something of a shared ethic here with Aristotle's early modern readers.

102. A. Brett, "What Is Intellectual History Now?," in What Is History Now?, ed. D. Cannadine (Basingstoke: Palgrave Macmillan, 2002), 113-32. 